Vol. 4, No. 4, 2019

\title{
ASSESSMENT OF HEAVY METAL CONTAMINATION OF THE TECHNOECOSYSTEM OF THE KAKHOVKA MAIN CANAL OF THE KAKHOVKA IRRIGATION SYSTEM
}

\author{
Liudmyla Khokhlova, Dmytro Lukashev \\ Taras Shevchenko National University of Kyiv, \\ Educational and Scientific Center "Institute of Biology and Medicine", \\ 2, Hlushkova Avenue, Kyiv, 03127, Ukraine \\ kherson.lyudmila@ukr.net,ecologyknu@gmail.com
}

https://doi.org/10.23939/ep2019.04.197

Received: 27.09.2019

(C) Khokhlova L., Lukashev D., 2019

\begin{abstract}
In the present study, the authors demonstrate the accumulation of heavy metals in water and soft tissues of bivalve mollusks (Dreissena polymorpha, Dreissena bugensis) in the Kakhovka Main Canal within the Kherson and Zaporizhzhia regions (Ukraine) in the summer season (July-August 2018). The average metal concentrations in water decrease in the following order: $\mathrm{Ni}>\mathrm{Zn}>\mathrm{Cr}>\mathrm{Co}>\mathrm{Cu}>\mathrm{Cd}$. On the whole, the accumulation of metals in soft tissues of the investigated bivalve mollusk species was higher than in the samples of water, since Dreissena are effective bio-accumulators. The average metal concentrations in soft tissues decrease in the following order: $\mathrm{Zn}>\mathrm{Cr}>\mathrm{Ni}>\mathrm{Cu}>\mathrm{Co}>\mathrm{Cd}$. At the end of the canal, at the 132nd $\mathrm{km}$ (Zaporizhzhia region), where older individuals prevailed, heavy metals were accumulated most $-159.04 \mathrm{mg} / \mathrm{kg}$.
\end{abstract}

Key words: Dreissena, canal, heavy metals, bioaccumulation, background concentration.

\section{Introduction}

Ukraine possesses a unique natural resource potential and is one of the richest agricultural countries in the world. The largest part (more than 2/5) of agricultural land is located in the South of Ukraine, in the zone of unstable and insufficient moisture [7], therefore, many meliorative objects were built here. The source of their filling is water from the Kakhovka reservoir on the Dnipro River [6]. The water management complex of the steppe zone is the most powerful in Ukraine. The Kakhovka Main Canal, one of the largest irrigation complexes in Europe, stretches from the Kakhovka
Reservoir to Molochna estuary and is $132 \mathrm{~km}$ long. The canal was constructed in 1980 for the irrigation of agricultural lands and water supply to populated places of Kherson and Zaporizhzhia regions [6]. In modern conditions of management, the quality of irrigation water is of paramount importance for the efficient and environmentally safe use of irrigated land in order to grow environmentally friendly products [5].

Water in irrigation systems can contain various pollutants, including heavy metals. Studies show that the water of the Kakhovka reservoir as a source of filling for the main canal can be contaminated with heavy metals $[2,12,18]$. Long-term observations have shown that $40 \%$ of irrigation water is unsuitable for the use [5, 26, 34]. Heavy metals are resistant to degradation in natural conditions and can accumulate in aquatic organisms and aquatic plants [3,22]. The bivalve mollusks now serve as a classical marker group of the structural and functional organization of hydrobiocenosis sensitive to environmental factors $[9,16]$. Bivalves of the genus Dreissena are considered valuable organisms for monitoring the state of the aquatic environment and are used as biomonitors $[10,17]$. In freshwater reservoirs, bivalves are often the dominant component of benthic and periphyton groups. In the Kakhovka reservoir, two species are most common Dreissena polymorpha and Dreissena bugensis [19]. Migration to the main canal and colonization of solid substrates by these species of mollusks began from the moment of its functioning and continues to this day. In the technical aspect, Dreissena is harmful in the canal, it attaches to water pipes, concrete slabs, pumping station units, and creates bio-interference in the operation of artificial watercourses. At the same time, bivalve 
mollusks in water bodies act as natural biofilters and water purifiers from the pollutants present in it, in particular, heavy metals and suspended particles [27]. Therefore, a detailed study of bivalves is necessary for a proper understanding of many biological processes occurring in irrigation objects. Their role in the natural improvement of water quality in the irrigation systems of developing countries is especially important in modern conditions. Similar studies in the world were carried out mainly at the irrigation systems of Egypt [24, 28], Bangladesh [11], Poland [22, 31], Turkey [8] and China [35].

The current study aims to evaluate the reserves of heavy metals accumulated in water and soft tissues of Dreissena in the Kakhovka Main Canal of the Kakhovka irrigation system within the Kherson and Zaporizhzhia regions (Ukraine) in the summer season (July-August 2018). To achieve this goal it was necessary to perform the following tasks: 1) To determine the concentration of heavy metals in the canal's water and assess the degree of pollution; 2) To establish the density of bivalves settlements in the canal and their frequency distribution; 3) To assess the reserves of heavy metals accumulated in the soft tissues of Dreissena in different parts of the irrigation canal.

\section{Experimental and theory part}

The Kakhovka Main Canal of the Kakhovka irrigation system stretches from the Kakhovka reservoir (Kherson region, 46 $48^{\prime} 55^{\prime \prime} \mathrm{N}, 33^{\circ} 366^{\prime} 51^{\prime \prime} \mathrm{E}$ ) and ends within the Zaporizhzhia region $\left(46^{\circ} 25^{\prime} 31^{\prime \prime} \mathrm{N}, 35^{\circ} 01^{\prime} 59^{\prime \prime} \mathrm{E}\right)$. The water is supplied to the receiving pool by the Main Pumping Station (MPS) with a capacity of up to $530 \mathrm{~m}^{3} / \mathrm{s}$ to a height of $25 \mathrm{~m}$, from where it flows by gravity to users. The canal is covered with concrete slabs with the use of anti filtration soil and concrete-film screens. Its width is 64-83 meters and the depth is 7.5-8.0 $\mathrm{m} \mathrm{[27].}$

Samples of water and bivalves were collected in parallel from six areas along the canal in the summer season (July-August 2018), starting from the gas station (area of the Kakhovka hydroelectric power station, MPS, the beginning of the canal) and ending with the area of the enclosing structure at the $132 \mathrm{~km}$ (the end of the canal) (Fig. 1).

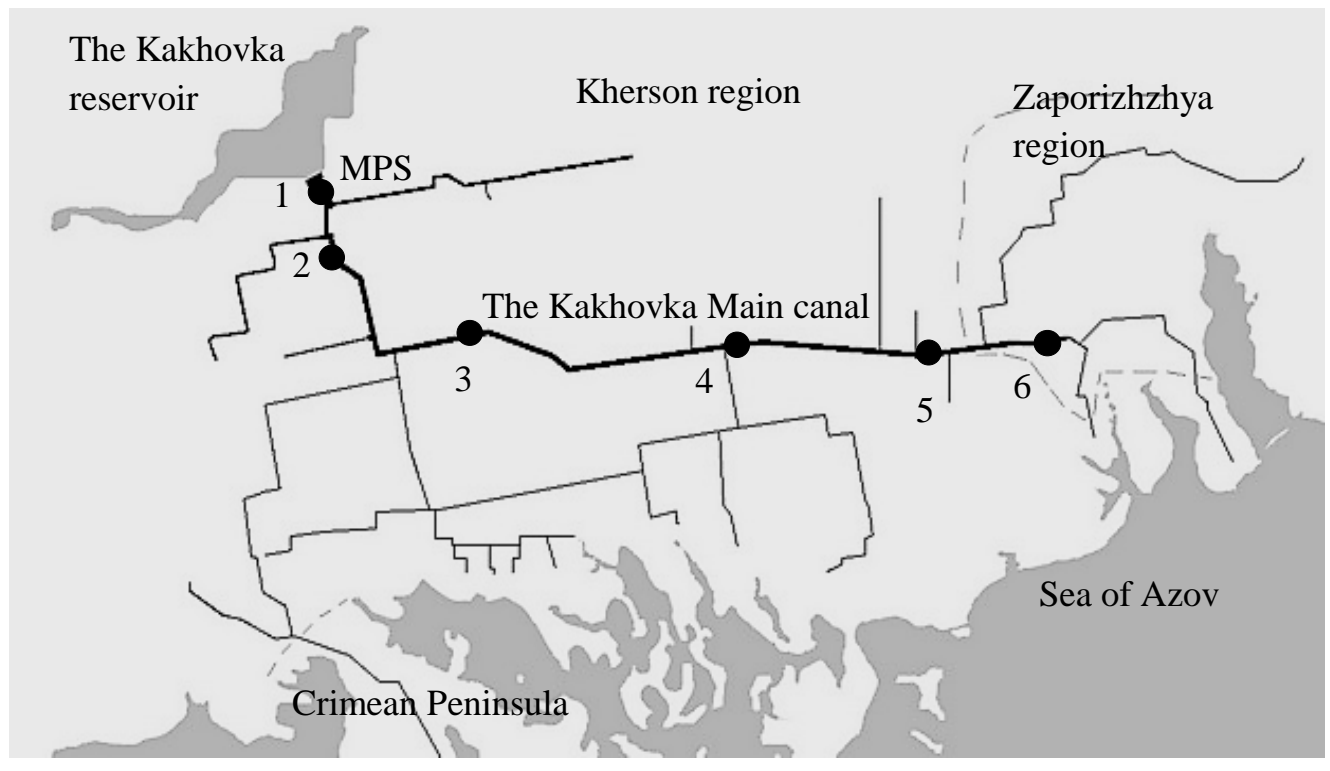

Fig. 1. Sampling points in the Kakhovka Main canal

Hydrobionts were selected according to standard generally accepted hydrobiological methods [1, 21]. Dreissena from solid substrates was collected using a hydrobiological scraper (blade width $10 \mathrm{~cm}$ ) or manually from a depth of 1.0-3.0 m. When sampling, the diving equipment was used. Live bivalves were washed with running water, cleaned with hard plastic brush from algae plaque and byssus, placed in plastic bags and then frozen. After thawing at room temperature and rinsing six times with deionized water, the soft tissues were dried to a constant weight for 24 hours at $80^{\circ} \mathrm{C}$. Dried samples were weighed, homogenized by grinding in a porcelain mortar, and stored in plastic containers flushed with $\mathrm{HNO}_{3}$ for further mineralization. Samples of bivalve soft tissues were subject to mineralization prior to the analysis of metal concentration. Approximately $2.0-0.2 \mathrm{~g}$ of dry weight was digested in $4 \mathrm{ml}$ of concentrated nitric acid at $95^{\circ} \mathrm{C}$ for 1 hour.

At a distance of 10-20 $\mathrm{m}$ from the shore from a depth of $0.5 \mathrm{~m}$, water samples were taken into $1.5-1$ plastic bottles. The water was sampled near the surface $(20-\mathrm{cm}$ below the water table) into $1.5-\mathrm{L}$ plastic bottles. Two 
replicates from each sampling site were collected. The water was immediately filtered through a paper filter (blue ribbon), and $4 \mathrm{ml}$ of $\mathrm{HNO}_{3}$ was added for preservation and subsequent analyzes.

We did not select bottom sediments in the canal due to strong turbidity due to high turbulence during the supply of large volumes of water for irrigation during the growing season. Also, the results of previous studies, in which it was shown that the maximum content of metals in water often corresponds to their minimum values in bottom sediments, were taken into account [15]. The concentrations of $\mathrm{Cd}, \mathrm{Co}, \mathrm{Cr}, \mathrm{Cu}, \mathrm{Zn}$, and $\mathrm{Ni}$ in the investigated samples were determined by a flame atomic absorption spectrophotometer SELMI C-115-M1 equipped with hollow-cathode lamps. The calibration was performed using standard analytical solutions. The concentration of metals in the soft tissues of mollusks was measured in $\mathrm{mg} / \mathrm{kg}$ of dry matter mass, and in water - in $\mathrm{mg} / \mathrm{dm}^{3}$.

The following species were identified: $D$. polymorpha and $D$. bugensis. Although these species often make up bottom settlements [27], in the conditions of the main canal of the community, Dreissena were concentrated in periphyton on solid substrates: concrete slabs and crushed stones. Particularly dense settlements are noted in the area of joints of concrete slabs. Shell length (L, maximum measure along the anterior-posterior axis) of each bivalve was measured using $0.01 \mathrm{~mm}$ precision caliper.

\section{Results and discussion}

Analysis of the heavy metal content in the water showed that their concentration at the investigated points is within the standards established in Ukraine: Sanitary Rules and Regulations 4630-88 [32] and State Standard of Ukraine (DSTU) 7286:2012 [33] (Table 1). The average metal concentrations in the water decrease in the following order: $\mathrm{Ni}>\mathrm{Zn}>\mathrm{Cr}>\mathrm{Co}>\mathrm{Cu}>\mathrm{Cd}$. The spatial difference in the metal concentrations in the water was observed for all the chemical elements except $\mathrm{Cd}$. The highest content of $\mathrm{Cu}, \mathrm{Ni}$, and $\mathrm{Co}$ was found in the water samples from the central section of the main canal (Point 4 (the $85 \mathrm{th} \mathrm{km})$ ), the lowest content was found in the initial section (Point 1 (the 2nd $\mathrm{km}$ )). At all the sampling points, the concentration of $\mathrm{Cd}$ was below the detection threshold of the analytical method. The highest $\mathrm{Zn}$ concentrations in the water were found at the initial and central sections of the irrigation canal -0.069 and $0.061 \mathrm{mg} / \mathrm{dm}^{3}$ respectively, while the lowest $\mathrm{Zn}$ concentration was observed at Point 2 (the 15 th $\mathrm{km}$ ) $-0.002 \mathrm{mg} / \mathrm{dm}^{3}$ and Point 6 (the $132 \mathrm{nd} \mathrm{km}$ ) $-0.005 \mathrm{mg} / \mathrm{dm}^{3}$. A gradual increase in $\mathrm{Cr}$ content in the water is observed from the initial section: Point 1 (the $2 \mathrm{nd} \mathrm{km}$ ) $-0.003 \mathrm{mg} / \mathrm{dm}^{3}$ to the final section of the canal. A slight decrease in concentration occurs at the end of the irrigation facility, and it is equal to $0.005 \mathrm{mg} / \mathrm{dm}^{3}$. The highest $\mathrm{Cr}$ content was observed at Point 3 (the 45th $\mathrm{km}$ ) $-0.009 \mathrm{mg} / \mathrm{dm}^{3}$. $\mathrm{Ni}$ and $\mathrm{Zn}$ were the dominant metals in the water.

Table 1

Average values of heavy metal concentration in the water of the Kakhovka Main Canal

\begin{tabular}{|c|c|c|c|c|c|c|}
\hline \multirow{2}{*}{ Sampling points } & \multicolumn{5}{|c|}{ Results of the analyzes $\left(\mathrm{mg} / \mathrm{dm}^{3}\right)$} \\
\cline { 2 - 7 } & $\mathrm{Cu}$ & $\mathrm{Ni}$ & $\mathrm{Co}$ & $\mathrm{Cd}$ & $\mathrm{Zn}$ & $\mathrm{Cr}$ \\
\hline 1 (the 2nd km) & 0.001 & 0.015 & 0.002 & $<0.001$ & 0.069 & 0.003 \\
\hline 2 (the 15th km) & 0.001 & 0.042 & 0.005 & $<0.001$ & 0.002 & 0.006 \\
\hline 3 (the 45th km) & 0.007 & 0.046 & 0.005 & $<0.001$ & 0.021 & 0.009 \\
\hline 4 (the 85th km) & 0.008 & 0.056 & 0.007 & $<0.001$ & 0.061 & 0.008 \\
\hline 5 (the 110th km) & 0.007 & 0.056 & 0,005 & $<0.001$ & 0.012 & 0.006 \\
\hline 6 (the 132nd km) & 0.003 & 0.038 & 0.004 & $<0.001$ & 0.005 & 0.005 \\
\hline
\end{tabular}

The relatively low heavy metal content is explained by the fact that the main sources of pollution of industrial cities of the Zaporizhzhia region, Energodar do not directly affect the power supply of the main canal - the Kakhovka reservoir and the water quality in it [30]. The low metal concentrations in the canal water are related to their precipitation on the suspended particles, with their subsequent deposition, accumulation by hydrobionts, mainly bivalve mollusks and blue-green algae. In this way, the processes of self-purification of the ecosystem of the irrigation facilities occur at low flow. Also, the aridity of the climate contributes to the formation of evaporating physicochemical barriers of natural genesis on the territory of laying the main canal $[6,34]$. There are no large industrial facilities on the areas adjacent to the main canal. However, the main sources of heavy metal contamination of the artificial water body may be breeding farms, household wastewater, and surface runoff from farmland [30]. The fact should be noted that some water contaminants like copper and zinc, which become extremely toxic at high concentrations, could naturally be present in small trace amounts. Their presence at low concentrations is important for maintaining the biological functions of aquatic ecosystems [29]. 
Thus, the quality of surface water at the sampling points met the environmental safety requirements for irrigation and water supply in summer. The obtained data are consistent with the information on surface water monitoring of the State Agency for Water Resources of Ukraine. The obtained data on the heavy metal content in the water are similar to those obtained from the studies of the Dnipro ecosystem [15] and slightly differ from those of the Maltese Reservoir (Western Poland) [31]. The concentrations of $\mathrm{Cu}, \mathrm{Cd}$, and $\mathrm{Zn}$ in the water of the main canal are almost identical to the concentrations of these chemical elements in the irrigation water of large water supplies of the Poltava region (Ukraine) [13].

All the investigated metals were detected in the soft tissues of Dreissena (Table 2). The average metal concentrations decreased in the following order: $\mathrm{Zn}>\mathrm{Cr}>\mathrm{Ni}>\mathrm{Cu}>\mathrm{Co}>\mathrm{Cd}$. In general, the metal accumulation in soft tissues of the studied species of bivalve mollusks was higher than in the water samples. This is mainly due to the extraction of metals by the hydrobionts from water and their accumulation in the body. Besides, the metal content in water can be seasonal and may not reflect the problem of contamination.

\section{Quantitative parameters of settlements of Dreissena and levels of heavy metal accumulation in their tissues}

Table 2

\begin{tabular}{|c|c|c|c|c|c|c|c|c|}
\hline \multirow{2}{*}{ Sampling points } & \multicolumn{2}{|c|}{$\begin{array}{l}\text { Quantitative parameters of } \\
\text { settlements }\end{array}$} & \multicolumn{6}{|c|}{ Metal concentration $(\mathrm{mg} / \mathrm{kg})$} \\
\hline & $\begin{array}{c}\text { Quantity } \\
\left.\text { (specimens } / \mathrm{m}^{2}\right)\end{array}$ & $\begin{array}{c}\text { Biomass } \\
\left(\mathrm{g} / \mathrm{m}^{2}\right)\end{array}$ & $\mathrm{Cu}$ & $\mathrm{Ni}$ & Co & $\mathrm{Cd}$ & $\mathrm{Zn}$ & $\mathrm{Cr}$ \\
\hline 1 (the $2 \mathrm{nd} \mathrm{km})$ & 684 & 382.8 & 9.26 & 16.01 & 1.12 & 0.86 & 61.00 & 15.79 \\
\hline 2 (the 15 th km) & 628 & 481.4 & 16.05 & 12.92 & 0.67 & 0.67 & 70.50 & 20.60 \\
\hline 3 (the 45th km) & 684 & 426.7 & 11.36 & 20.82 & 0.13 & 0.87 & 87.83 & 28.09 \\
\hline 4 (the 85th km) & 906 & 472.4 & 8.80 & 21.32 & 1.42 & 0.74 & 76.83 & 29.77 \\
\hline 5 (the 110th km) & 738 & 530.6 & 6.95 & 13.05 & 0.63 & 0.63 & 59.87 & 23.72 \\
\hline 6 (the $132 \mathrm{nd} \mathrm{km}$ ) & 316 & 298.3 & 15.71 & 21.79 & 1.79 & 0.71 & 89.93 & 29.11 \\
\hline
\end{tabular}

The quantitative composition of mollusks settlements in artificial streams of great length undergoes significant changes along the route from the initial sections to the final ones [27]. This is confirmed by the results of the study, which show the size and frequency variability of the structure of the Dreissena settlements and their uneven distribution along the axis of the reservoir. It is probably caused by several environmental factors: temperature, flow velocity, depth differences in the hydraulic engineering structure, transparency of the aquatic environment, the amount of phytoplankton along the route, etc. As shown by the data in Table 2, the total biomass of D. polymorpha and D. bugensis on solid substrates in summer averaged $432.03 \mathrm{~g} / \mathrm{m}^{2}$ and its density was about 660 specimens per square meter. For comparison, according to the research conducted by the Institute of Hydrobiology of the USSR Academy of Sciences in the 1980s, in the first years of operation in the Kakhovka Main Canal, the total biomass of Dreissena on concrete slabs and crushed stone was $630.9 \mathrm{~g} / \mathrm{m}^{2}$ and its density was 37 thousand specimens per square meter [27]. The largest number of mollusks was observed at Point 4 (the 85th km) - 906 specimens per square meter and Point 5 (the 110th km) - 738 specimens per square meter, the lowest one was observed at Point 6 (the 132nd km) 316 specimens per square meter. The largest biomass was observed at Point 5 (the 110 th $\mathrm{km}$ ) $-530.6 \mathrm{~g} / \mathrm{m}^{2}$ at 738 specimens per square meter, the smallest one of $298.3 \mathrm{~g} / \mathrm{m}^{2}$ was observed at the end of the canal.. The biomass of mollusks and the degree of heavy metal absorption by the surface depends on the size and age parameters. The maximum mollusks shell length rarely exceeds $30 \mathrm{~mm}$ [4]. Medium-sized sexually mature mollusks dominated in the reclamation facility, and there were no individuals larger than $29 \mathrm{~mm}$ in size. Earlier, Dreissena individuals that reached $35 \mathrm{~mm}$ in length by the age of 4 years were found in the Kakhovka Main Canal [27]. The modal size class for Dreissena were individuals of 12-19 mm medium length. The canal section at a distance of up to $45 \mathrm{~km}$ from the Main Pumping Station is mainly populated by mollusks that came from the Kakhovka Reservoir at the larval stage. At a distance of 45-110 km from the pumping station, mollusks settlements of a mixed origin are formed. In the final sections, they consist mainly of indigenous mollusks born directly in the canal. In the farthest area of the reclamation facility (the Zaporizhzhia region), sparse Dreissena settlements, which consist of individuals of older age groups, are formed. In general, the Dreissena settlements in the main canal are perennial entities that consist of individuals of at least 3-4 age groups and the size of their individuals is optimal for the use in bioindication.

As shown in [14], the average heavy metal concentrations in soft tissues of bivalve mollusks from 
unpolluted freshwater reservoirs were the following: for $\mathrm{Cd} \sim 1 \mathrm{mg} / \mathrm{kg}$, for $\mathrm{Cu} \sim 10-12 \mathrm{mg} / \mathrm{kg}$, for $\mathrm{Zn} \sim 100-$ $120 \mathrm{mg} / \mathrm{kg}$. For cadmium and zinc, no significant excess of these levels was observed in soft tissues at the investigated sampling points (Table 2). The excess of copper content was observed at two points: Point 2 (the 15 th $\mathrm{km}$ ) $-16.05 \mathrm{mg} / \mathrm{kg}$ and Point 6 (the 132nd km) $15.71 \mathrm{mg} / \mathrm{kg}$. The upper limit of the background level of $\mathrm{Cu}$ content is considered to be $\sim 16.7 \mathrm{mg} / \mathrm{kg}$ [17], i.e. the concentration of copper at Point 2 is close to the limit. As stated in [20], the concentration of $\mathrm{Cu} \sim 32 \mathrm{mg} / \mathrm{kg}$ can be considered as corresponding to the contaminated conditions of mollusks existence. The smallest content of cobalt was observed at Point 3 (the 45th $\mathrm{km}$ ) $0.13 \mathrm{mg} / \mathrm{kg}$, the highest one was observed at the end of the canal $-1.79 \mathrm{mg} / \mathrm{kg}$, which slightly exceeds the upper limit of the background $~ 1.17 \mathrm{mg} / \mathrm{kg}$ [17]. High concentrations of nickel that exceed the upper limit of the background $\sim 14.2 \mathrm{mg} / \mathrm{kg}$ [17] were observed in almost all the investigated areas except Point 12 (the 15 the $\mathrm{km}$ ) $12.92 \mathrm{mg} / \mathrm{kg}$ and Point 5 (the 110th km) - $13.05 \mathrm{mg} / \mathrm{kg}$. For mollusks from unpolluted ecosystems, the content of this metal is $0.7-1.7 \mathrm{mg} / \mathrm{kg}$. In Ukraine, the Dreissena accumulates $\mathrm{Ni}$ within $5.7-20.5 \mathrm{mg} / \mathrm{kg}$ [17]. The increased values of chromium content were recorded throughout the canal; the average value was $24.51 \mathrm{mg} / \mathrm{kg}$. According to [25], in uncontaminated reservoirs, the Dreissena accumulates about $1.2-3.5 \mathrm{mg} / \mathrm{kg}$ of $\mathrm{Cr}$. The analysis of the spatial distribution of heavy metals in mollusks tissues did not show any regular change in the content of most metals along the canal bed, except for chromium, the concentration of which increases from the initial sections and reaches $29.11 \mathrm{mg} / \mathrm{kg}$ at the end of the canal The high heavy metal content in tissues of mollusks at the end of the canal may be related not only to the size of mollusks (due to the dominance of large forms) and the absorption degree but also to the hydrochemical features of the remote regulated section of the canal (the presence of sluices). At these sections, the mollusks mostly accumulate heavy metals $-159.04 \mathrm{mg} / \mathrm{kg}$ at low biomass and a low number of their settlements. In the authors' study, the metal accumulation degree in the soft tissues did not correspond to the same order and spatial changes as in the water. The data obtained do not coincide with the results of other studies [15, 31], in which the metal accumulation level in soft tissues followed the tendency to change, as in water samples, thus indicating a strong relationship between environmental and biological concentrations. The authors' studies are close to the findings on the heavy metal migration in different parts of the aquatic ecosystem of the Uda River (within the Kharkiv region, Ukraine) [23].

It should be considered that while sedimenting heavy metal compounds, the mollusks transfer them to bottom sediments after the death [27], which, in turn, can lead to their supersaturation and deterioration of the reservoir status. However, as the authors' research shows, the water quality of the canal complied with the established standards. This probably affects the decrease in the number of mollusks as a result of operational cleaning of the canal, their significant consumption by predators and freshwater cyprinids, and death rate heightening processes in summer as a result of abnormal spikes in temperature that often occur in the South of Ukraine [27].

The authors believe that the results of the studies should be interpreted with caution since one-year summer observations may not show the general state of the canal pollution, and a multi-year analysis must be carried out. In further studies, it must be considered that the availability and absorption of heavy metals by mollusks depend on many factors: $\mathrm{pH}$ of water, temperature, the concentration of nutrients, total organic matter content, etc.

\section{Conclusions}

Due to the low metal concentrations in the water of the main canal, which are within the established limits, the study has shown that bivalve mollusks are not only an effective indicator, which is sensitive to pollution but also bio-accumulators that can accumulate heavy metals in their tissues, thus improving water quality [10]. Their optimum size, limited mobility, prevalence and abundance in freshwater, the relative ease of collection and identification of species are important advantages of these organisms. The metal accumulation in soft tissues of studied species of bivalve mollusks was higher than the one in the water samples. The mollusks' biomass and the heavy metal absorption degree by tissues depend on the size and age parameters. The modal size class for Dreissena were individuals of 12-19 mm medium length. As expected, there was the largest heavy metal accumulation at the end of the canal at the 132nd km (Zaporizhzhia region), where individuals of older age groups prevailed. The metal accumulation degree in soft tissues did not correspond to the same order and spatial changes as in water. In general, about $774.34 \mathrm{mg} / \mathrm{kg}$ of heavy metals were extracted and accumulated by mollusks in the studied areas. The obtained indicators of the background metal content in the tissues of mollusksaccumulators can be used in practice as criteria for the pollution of aquatic ecosystems in the study of artificial water bodies that do not have stationary observation posts.

\section{References}

[1] Abakumov V. Rukovodstvo po metodam gidrobiologicheskogo analiza poverkhnostnykh vod i donnykh oblozheniy. Gidrometeoizdat, Leningrad 1983. 
[2] Andrusishina I., Andreychenko S., Golub I. Aktual'nyye problemy transportnoy meditsiny, 2005, 1, 106.

[3] Arnason J., Fletcher B. Environmental Pollution, 2003, 123, 383.

[4] Balan P., Vekslyars'kyy R., Verves Y. Model'ni hrupy bezkhrebetnykh tvaryn yak indykatory radioaktyvnoho zabrudnennya ekosystem. Fitosotsiotsentr, Kyiv 2001.

[5] Balyuk S., Vorotyntseva L., Drozd O. Propozytsiya nova, 2013, 12, 60.

[6] Boyko M., Chornyy S. Ekolohiya Khersonshchyny. Ekotsentr, Kherson 2001.

[7] Danylyshyn B., Dorohuntsov S. Pryrodno-resursnyy potentsial staloho rozvytku Ukrayiny. Nichlava, Kyiv 1999.

[8] Demirak A., Yilmaz F., Ozdemir N. Chemosphere, 2006, 63, 1451.

[9] Dombrovs'kyy K. Visnyk Zaporiz'koho natsional'noho universytetu. Biolohichni nauky, 2009, 2, 30.

[10] Elder J., Collins J. Rev Environ Contam Toxicol, 1991, $122,37$.

[11] Gawsia, W., David, C. Freshwater Science, 2016, 35, 188.

[12] Hnatyuk V., Pidhornyy N. IV-y vseukrayins'kyy z"yizd ekolohiv z mizhnarodnoyu uchastyu, Ukraine,Vinnytsya 2013, 232.

[13] Koval' V., Kucheryavyy S., Natalochka V. Visnyk Poltavs'koyi derzhavnoyi ahrarnoyi akademiyi, 2014, 2, 58.

[14] Kwan K., Chan H., Lafontaine Y. Environmental monitoring and assessment, 2003, 88, 193.

[15] Lukashev D. Gidrobiologicheskiy zhurnal, 2006, 1, 86.

[16] Lukashev D. Gidrobiologicheskiy zhurnal, 2011, 3, 44.

[17] Lukashev D. Gidrobiologicheskiy zhurnal, 2008, 44, 60.

[18] Lyanzberg O., Suslyak M. IV Mizhnarodniy ekologichniy forum "Chyste MISTO. Chysta RIKA. Chysta PLANETA", Ukraine, Kherson 2012,153

[19] Mal'tsev V., Zub L., Karpova G. Vodno-bolotnyye ugod'ya Dneprovskogo ekologicheskogo koridora. Institut ekologii INEK, Kyiv 2010.
[20] Mersch J., Johansson L. Environmental technology, 1993,14, 1027.

[21] Metody hidroekolohichnykh doslidzhen' poverkhnevykh vod / Arsan O. M., Davydov O. A., D'yachenko T. M. ta in.; Za red. V. D. Romanenka, NAN Ukrayiny. In-t hidrobiolohiyi. LOHOS, Kyiv 2006.

[22] Milošković A., Branković S., Simić V. Bulletin of Environmental Contamination and Toxicology, 2013, 90, 563.

[23] Miroshnichenko O. Visnyk KHNU imeni V. N. Karazina, 2013,1054, 91.

[24] Mohamed E. The Egyptian Journal of Aquatic Research, 2014, 40, 225.

[25] Nikanorov A., Zhulidov A. Biomonitoring metallov v presnovodnykh ekosistemakh. Gidrometeoizdat, Leningrad 1991.

[26] Obukhov E. Ekonomika Ukrainy, 2017, 1, 31.

[27] Oksiyuk O., Oleynik G., Shevtsova L. Gidrobiologiya kanalov Ukrainskoy SSR. Naukova dumka, Kyiv 1990.

[28] Osman M., Mohamed E. Nature and Science, 2010, 8, 60.

[29] Parfenova G. Antropogennyye izmeneniya gidrokhimicheskikh pokazateley kachestva vod. Agrafpress, Tomsk 2010.

[30] Rehional'na dopovid' pro stan navkolyshn'oho pryrodnoho seredovyshcha u Khersons'kiy, Zaporiz'koyi oblasti za 2015-2017 roky. Elektronnyy resurs. Rezhym dostupu: http://www.menr.gov.ua.

[31] Rzymski P., Klimaszyk P. Environmental monitoring and assessment, 2014, 185, 162.

[32] SANPin 4630-88. Sanitarnyye pravila i normy okhrany poverkhnostnykh vod ot zagryazneniya. Izdatelstvo Minzdrava SSSR, Moskva 1988.

[33] Yakist' pryrodnoyi vody dlya zroshuvannya. Ekolohichni kryteriyi. DSTU 7286:2012. Vydannya ofitsiyne. NNTS "IHA imeni O.N. Sokolovs'koho, Kyiv 2013.

[34] Yehorova T. Melioratsiya i vodne hospodarstvo, 2014, $101,231$.

[35] Zhao L., Yang F., Yan X., Huo Z. Biological Trace Elements Research, 2012, 149, 241. 